\title{
Extraction and Quantitative HPLC Analysis of Coumarin in Hydroalcoholic Extracts of Mikania glomerata Spreng. ("guaco") Leaves
}

\author{
Renata M. S. Celeghini, Janete H. Y. Vilegas and Fernando M. Lanças* \\ Instituto de Química de São Carlos, Universidade de São Paulo, CP 780, 13560-970, São Carlos - SP, Brazil
}

\begin{abstract}
Foram avaliados vários métodos de extração para os extratos hidroalcoólicos das folhas de "guaco" (Mikania glomerata Spreng.): maceração, maceração com ultra-som, infusão e extração por fluido supercrítico. Dentre os métodos estudados, a maceração com ultra-som proporcionou os melhores resultados, especialmente considerando-se a relação rendimento da extração/ tempo de extração. A cromatografia líquida de alta eficiência (CLAE) foi utilizada para determinar a concentração de cumarina nos extratos hidroalcoólicos das folhas de "guaco". A metodologia de análise desenvolvida utilizando CLAE mostrou ser sensível e reprodutível.
\end{abstract}

\begin{abstract}
Methods for preparation of hydroalcoholic extracts of "guaco" (Mikania glomerata Spreng.) leaves were compared: maceration, maceration under sonication, infusion and supercritical fluid extraction. Evaluation of these methods showed that maceration under sonication had the best results, when considering the ratio extraction yield/extraction time. A high performance liquid chromatography (HPLC) procedure for the determination of coumarin in these hydroalcoholic extracts of "guaco" leaves is described. The HPLC method is shown to be sensitive and reproducible.
\end{abstract}

Keywords: Mikania glomerata Spreng (Compositae), coumarin, high performance liquid chromatography (HPLC), extraction techniques

\section{Introduction}

For a safe utilization of any medicinal plant as a medicine, its standardization is necessary to guarantee the plant drug authenticity and its content of active principles according of the parameters utilized as quality criteria. Chromatographic methods can be applied for the quality control of medicinal plants due to their many advantages such as high efficiency, speed and the possibility of their utilization in automatized systems.

For the genus Mikania, about 415 species are mentioned, distributed mainly in Central and South America, with 171 species being in Brazil ${ }^{1}$. In the present study we have studied Mikania glomerata Spreng. (Compositae), this being the only one registered in the Brazilian Pharmacopeia (First edition) ${ }^{2}$. This plant is a sub-scrub creeper of woody branches and brilliant-green leaves that exhale a strong aroma reminiscent of vanilla. It is known popularly in Brazil as "guaco", "guaco liso", "guaco de cheiro" and "cipó caatinga"3.

In spite of its vast popular applications, the literature has few scientific studies about "guaco" action. The

\footnotetext{
*e-mail: flancas@iqsc.sc.usp.br
}

pharmacological effects of the hydroalcoholic extracts prepared from the "guaco" leaves were studied ${ }^{4}$. Antiinflammatory activity has been observed in in vitro pharmacological tests and an inhibiting effect of the intestinal and uterine musculature in vivo. Other tests have also indicated bronchodilating activity, while coumarin (1) was shown to be responsible for about 50 to $60 \%$ of this activity in relation to the total activity of the crude extract ${ }^{5}$.

A capillary gas chromatographic (HRGC) method has been described for the quantitative analysis of coumarin and kaurenoic acid in hexane extracts of $M$. glomerata leaves ${ }^{6}$. For analysis of hydroalcoholic extracts, a thin layer chromatographic method has been proposed ${ }^{7}$. However, no instrumental chromatographic method for the standardization of hydroalcoholic extracts of $M$. glomerata leaves has been reported. In this work, the extraction and chromatographic conditions for coumarin analysis in hydroalcoholic extracts of M. glomerata leaves were studied. Several conventional and alternative extraction methods were evaluated, and coumarin was quantified by high performance liquid chromatography-ultraviolet diode array detection (HPLC-UV/DAD). 


\section{Experimental}

\section{Plant material}

Cultivated specimens of Mikania glomerata Spreng. (Compositae) were obtained by vegetative propagation of an authentic example classified by Dr. Ayrton Amaral Jr. (UNESP - Botucatu, SP, Brazil) and grown in Ribeirão Preto, SP, Brazil. A voucher specimen is deposited at UNESP-Botucatu herbarium (voucher number BOTU 19.813). Leaf material was collected in June 1995 by Ana Maria Soares Pereira (UNAERP) and dried at $40{ }^{\circ} \mathrm{C}$ with forced ventilation for 3 days before being powdered, sieved (only particles with $0.5-1.0 \mathrm{~mm}$ were utilized) and extracted.

\section{Extraction procedures}

Maceration. Powdered dried leaves (1 g) were macerated with ethanol:water $(1: 1 ; \mathrm{v} / \mathrm{v}, 10 \mathrm{~mL})$ and left at rest ( 7 days, room temperature). The material was filtered and the crude extract obtained was analyzed directly by HPLC-UV. This procedure was repeated in triplicate.

Maceration under sonication. Powdered dried leaves $(1 \mathrm{~g})$ were mixed with ethanol:water $(1: 1 ; \mathrm{v} / \mathrm{v}, 10 \mathrm{~mL})$ and macerated under sonication, (water bath, room temperature, $30 \mathrm{~min}$ ). The material was filtered and the crude extract obtained was analyzed directly by HPLC-UV. The procedure was repeated in triplicate.

The extractions were also made varying only the time interval of each ultra-sound extraction: $1,5,10,15,20,30$, 40, 50 and 60 minutes, for determination of the optimal time. Each extraction was repeated in triplicate.

For determination of efficiency of this extraction procedure, the same sample ( $1 \mathrm{~g}$ ) was successively extracted under sonication, for a total of three successive extraction cycles. This sequence was made in triplicate, and the extracts obtained in each cycle were analyzed directly by HPLC-UV.

Infusion. Powdered dried leaves ( $1 \mathrm{~g}$ ) were added to boiling distilled water $(10 \mathrm{~mL})$. The recipient was covered until reaching room temperature. This material was filtered and the crude extract obtained was analyzed directly by HPLC-UV. This procedure was repeated in triplicate.

Supercritical fluid extraction (SFE). The extractions were performed in a home-made system built in our laboratory ${ }^{8}$. A stainless steel extraction cell $(20 \mathrm{~cm}$ length x $0.7 \mathrm{~cm}$ i.d.) and a capillary fused silica restrictor (180 $\mu \mathrm{m}$ i.d.) were utilized for the extraction of powdered dried leaves $(1 \mathrm{~g})$. The solvent extraction system was pressurized in the high-pressure vessel (capacity: $500 \mathrm{~mL}$ ) with the aid of a nitrogen cylinder and extraction time was $20 \mathrm{~min}$. Several solvent mixtures were used including $\mathrm{CO}_{2}: \mathrm{EtOH}$ (95:5), (90:10), (85:15) and $\mathrm{CO}_{2}: \mathrm{EtOH}: \mathrm{H}_{2} \mathrm{O}(95: 2.5: 2.5)$, all at the same pressure (100 bar) and temperature $\left(70^{\circ} \mathrm{C}\right)$. These conditions were over the critical conditions, Tc and $\mathrm{Pc}$, as calculated following approximate equations described as $(\mathrm{Tc}=\mathrm{Ta} . \mathrm{xa}+\mathrm{Tb} . \mathrm{xb} ; \mathrm{Pc}=\mathrm{Pa} \cdot \mathrm{xa}+$ $+\mathrm{Pb} . \mathrm{xb})^{9}$. The extract was collected in an empty flask immersed in an ice bath. The crude extracts obtained were analyzed by thin layer chromatography (TLC).

Determination of optimal proportions of extraction solvent (EtOH: $\mathrm{H}_{2} \mathrm{O}$ ). Powdered dried leaves $(1 \mathrm{~g}$ ) were mixed in $10 \mathrm{~mL}$ ethanol:water in the following proportions, in relation to ethanol: $100,90,80,70,60$ and 50\%. These mixtures were extracted under sonication (water bath, room temperature, $20 \mathrm{~min}$ ). The extracts were filtered and the crude extracts obtained were analyzed visually and by thin layer chromatography (TLC).

\section{Chromatographic methods}

Thin layer chromatography. Thin layer chromatographic (TLC) analyses were made on $0.25 \mathrm{~mm}$ thick silica gel 60G (Merck, 7731), prepared on glass plates. As eluent a mixture of toluene:ethyl ether (1:1) saturated with $10 \%$ acetic acid was used; after solvent evaporation the plates were sprayed with an ethanolic solution $(5 \% \mathrm{v} / \mathrm{v})$ of $\mathrm{KOH}$. After spraying, the plate was examinated under UV light at $366 \mathrm{~nm}$. Coumarin (Sigma) was used as standard.

HPLC analysis. A modular Shimadzu LC-10 system comprised of a LC-10AD pump, a CTO-10A column oven, a SPD-10A UV-DAD detector, a CBM-10A interface and a LC-10 Workstation was utilized. A LC-18 column (250 mm x $4 \mathrm{~mm}$ i.d. x $5 \mathrm{~mm}$ ) from Supelco (Bellefonte, USA) was employed, at $30^{\circ} \mathrm{C}$. Separations were done in the isocratic mode, using acetonitrile:water (40:60; v/v) at a flow rate of $1 \mathrm{~mL} \mathrm{~min}^{-1}$; with an injection volume ("loop") of $20 \mu \mathrm{L}$; UV detection was at $274 \mathrm{~nm}$.

Quantitative analysis. Determination of the content of the coumarin in plant material was performed by the external standard method ${ }^{10}$, using pure coumarin (Sigma) as standard. Stock solutions of 1, 10, 20, 40, 60, 80 and $100 \mu \mathrm{g} / \mathrm{mL}$ were utilized. Each determination was carried out in triplicate.

\section{Results and Discussion}

\section{Quantitative analysis of coumarin}

The calibration curve showed the linearity of the detector over the tested range $(1-100 \mu \mathrm{g} / \mathrm{mL})$. The 
regression equation was $y=3392.87+88593.60 x$ $(r=0.99995)$. Average standard errors for the peak areas of replicate injections were smaller than $5 \%$, showing good repeatability of the calibration curve.

The HPLC-UV detection limit was $5 \mu \mathrm{g} \mathrm{L} \mathrm{L}^{-1}$. These results also showed a low noise level, good sensitivity of the detector at $274 \mathrm{~nm}$, and that the compound of interest could be analyzed in a satisfactory time interval of less than $6 \mathrm{~min}$.

\section{Comparison among the different extraction methods}

Since both maceration and maceration under sonication showed statistically similar results (Table 1), and as the extraction time of 7 days by maceration is very long for routine analysis, maceration under sonication was chosen, since it required a shorter extraction time $(20 \mathrm{~min})$.

Table 1. Coumarin content found in the extracts obtained by different extraction methods from a sample of $M$. glomerata leaves. For extraction procedures, see Experimental.

\begin{tabular}{lcc}
\hline Extraction process & $\begin{array}{c}\text { Coumarin concentration } \\
\pm \text { s.d. }\left(\mu \mathrm{g} / \mathrm{mL}^{-1}\right)\end{array}$ & Relative s.d. (\%) \\
\hline Maceration & $696.4^{*} \pm 34.6$ & 5.0 \\
Ultra-sound maceration & $656.2^{*} \pm 14.7$ & 2.2 \\
Infusion & $393.8 \pm 13.4$ & 3.4 \\
\hline
\end{tabular}

* non significant difference (t-test, $p=0.05)(\mathrm{n}=3)$

The extracts obtained by SFE could not be directly analyzed by HPLC, because they presented a high content of chlorophylls, which were detected by TLC. The cleanup of these samples was shown to be unfeasible. It was concluded that use of a polar modifier $(\mathrm{EtOH})$ in SFE for the coumarin extraction in samples of "guaco" did not present significant advantages in relation to the SFE method using $\mathrm{CO}_{2}{ }^{11}$. The latter, as indicated by HRGC analysis, offered an extract without high molecular weight compounds (including chlorophylls) and did not require a previous stage of "clean-up". Coumarin was detected by comparison with a standard.

\section{Optimization of maceration under sonication}

Through visual evaluation and TLC analysis, the best proportion of the extracting solvent was established as being ethanol:water $(1: 1 \mathrm{v} / \mathrm{v})$.
The extraction and two sequential reextraction tests (Table 2) showed that in the first extraction the coumarin percentage was $78.73 \%$, being reproducible (s.d. around $2 \%$ ) and not justifying the carrying out of serial extractions, because they would increase analysis time and solvent expense.

From the extraction data and kinetics (yield of extraction as a time function, Figure 1), the optimal extraction time using the mixture ethanol:water $(1: 1 \mathrm{v} / \mathrm{v})$ as the extracting solvent was determined. The inflection point of the curve was found at $20 \mathrm{~min}$, which was chosen as the optimal extraction time.

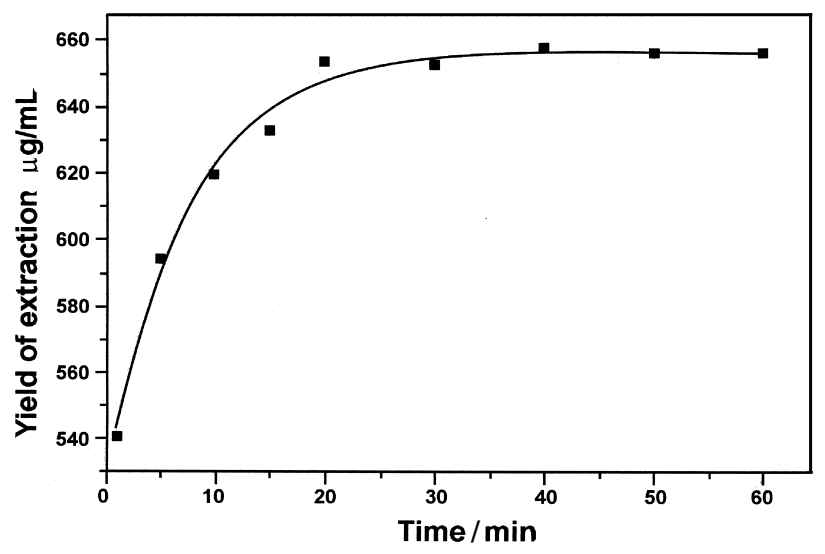

Figure 1. Yield of coumarin extraction as a time function, using maceration under sonication of Mikania glomerata Spreng.

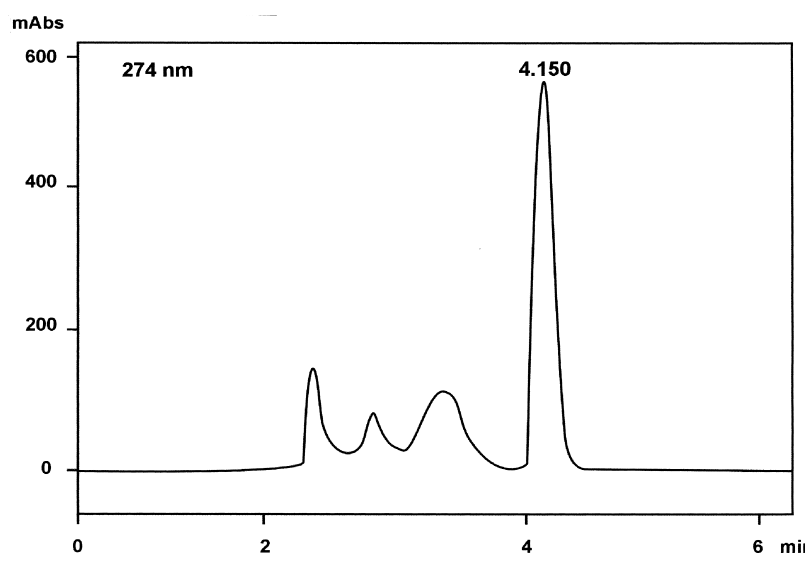

Figure 2. Chromatogram (HPLC-UV/DAD) of the hydroalcoholic extract of $M$. glomerata obtained by maceration under sonication (20min).

Table 2. Coumarin content after three successive extractions of the same sample of Mikania glomerata Spreng. For extraction procedures see Experimental.

\begin{tabular}{|c|c|c|c|}
\hline Sample & Concentration $\left(\mu \mathrm{g} \mathrm{mL}^{-1}\right) \pm$ s.d. & Relative s.d. (\%) & Relative extraction yield (\%) \\
\hline Dried leaves & $648.3 \pm 14.9$ & 2.3 & 78.7 \\
\hline Leaves after 1 st maceration & $140.4 \pm 2.2$ & 1.5 & 17.1 \\
\hline Leaves after 2nd maceration & $34.8 \pm 0.4$ & 1.2 & 4.2 \\
\hline
\end{tabular}


Figure 2 presents the chromatographic profile (HPLC-UV/ DAD) of a hydroalcoholic extract of $M$. glomerata obtained through maceration under sonication, after 20 min of sonication. The peak corresponding to coumarin can be observed right after $4 \mathrm{~min}$. No interference of other components is observed in the elution window corresponding to this target compound.

\section{Conclusions}

The results presented in this paper indicate that HPLCUV may be a useful tool for the quality control of hydroalcoholic extracts of $M$. glomerata, since this method showed reproducibility and sensitivity adequate for these extracts. As a sample preparation method, maceration under sonication showed to be the best choice, mainly considering the time/yield ratio.

\section{Acknowledgments}

The authors are grateful to Dr. Ana Maria Soares Pereira for furnishing plant material, and to CAPES, CNPq and FAPESP for fellowships and financial support.

\section{References}

1. King, R. M.; Robinson, H. Genera of the Eupatoreae
(Asteraceae); Lawrence; Allen, 1987.

2. Dias da Silva, R. A. Pharmacopéia dos Estados Unidos do Brasil; Companhia Editora Nacional; São Paulo, 1929.

3. Oliveira, F.; Alvarenga, M. A.; Akisue, G.; Akisue, M. K. Rev. Farm. Bioquim. Univ. S. Paulo 1984, 20, 169.

4. Silva, M. A. M.; Moreira, L. K. A.; Leite, M. G. R.; Viana, G. S. B.; Matos, F. J. A. In XII Simpósio de Plantas Medicinais do Brasil; U.F. Paraná; Curitiba; 1992, p.52.

5. Leite, M. G. R; Silva, M. A. M.; Lino, C. S.; Viana, G. S. B.; Matos, F. J. A. In XII Simpósio de Plantas Medicinais do Brasil; U.F. Paraná; Curitiba; 1992, p.21.

6. Vilegas, J. H. Y.; de Marchi, E.; Lanças, F. M. Phytochem. Anal. 1997, 8, 74.

7. Oliveira, F.; Saito, M. L.; Garcia, L. de O. In XII Simpósio de Plantas Medicinais do Brasil; Universidade Federal do Paraná; Curitiba; 1992, p. 96.

8. Sargenti, S. R.; Lanças, F. M. J. Chromatogr. A 1994, 667, 213.

9. Peaden, P. A.; Lee, M. L. Anal. Chem. 1996, 68, 487R.

10. Smith, R. M. Gas and Liquid Chromatography in Analytical Chemistry; John Wiley; Chichester, 1988.

11. Vilegas, J. H. Y.; de Marchi, E.; Lanças, F. M. Phytocphem. Anal. 1997, 8, 266.

Received: March 23, 2001

Published on the web: July 29, 2001

FAPESP helped in meeting the publication costs of this article. 